\title{
Assessment of Ground Water Quality in Sakara and Muraul Block of Muzaffarpur District, Bihar
}

\author{
Sanjay Kumar Singh \\ Department of Soil Science, Dholi Campus, Dr. Rajendra Prasad Central Agricultural University, \\ Samastipur-848125, Bihar, India
}

\begin{abstract}
A study was conducted to evaluate the ground water quality of 40 samples collected from the hand-pumps of different villages during pre and post monsoon period. The water quality parameters were analyzed to ascertain the potability of drinking water against recommended limits of WHO and BIS. The electrical conductivity for all the samples were above the WHO standards, while the bicarbonates in 81 per cent samples were found to be above critical level. The maximum TDS (680-748 $\left.\mathrm{mgL}^{-1}\right)$ value was recorded in Dholi village during post monsoon period. The bicarbonate concentration was found in all the samples and it was maximum in Sakara village while carbonates content was absent in these samples.
\end{abstract}

Keywords: BIS, physio-chemical characters, total solids dissolve, water quality

\section{Introduction}

Among the various sources, groundwater is the most important source of water supply throughout the world (Mariappan et al. 2005). The quality of ground water in some part of the country, particularly shallow ground water is changing due to human activities. Fresh ground water supply is necessary for human survival, as it is considered the only source of drinking water in rural areas and also for industrial development. The growing urbanization and industrialization have led to increased use of agro-chemicals in recent times, as well as improper and inadequate management of water systems that has caused serious problems of water availability and quality (Krishnan et al. 2007). About eighty per cent of our drinking water, which is depleting at an alarming rate compounded with large scale contamination. The water with a TDS above $500 \mathrm{mgL}^{-1}$ is not recommended for use as drinking water as per the EPA guidelines. It warrants periodical monitoring and evaluation based on standard water quality parameters to confirm its suitability for drinking and agricultural use (Ashfaq and Ahmad 2014) and also to work out the future plan for maintaining the water quality (Deshmukh and Urkude 2014). Hence, the present study was undertaken to determine the quality of groundwater being pumped out through hand pumps in some villages of Muzaffarpur district of Bihar.

*Corresponding author: (Email: sanjaybhu@rediffmail.com) 


\section{Materials and Methods}

The study was undertaken in 5 villages viz. Dholi, Muraul and Lautan representing Maraul block and Sakara and Sakara Bazitpur of Sakara block of Muzaffarpur district, Bihar. The average annual rainfall received during mid-June to first week of October was around $1187 \mathrm{~mm}$. The inhabitants of the area use drinking water in daily life either through privately or by public bored hand pump. A total of forty water samples (after 30 minutes of pumping) were collected from randomly selected hand pump during May (premonsoon) and October (post-monsoon), 2014 and transferred into pre-cleaned amber bottle and analyzed for $\mathrm{pH}, \mathrm{EC}$, TDS, Chloride, $\mathrm{CO}_{3}^{-}, \mathrm{HCO}_{3}^{-}$, phosphate, total alkalinity, total hardness, sodium and potassium following standard analytical procedures (Saxena 1987) and American Public Health Association (1989).

Analyzed parameters were compared with the standards prescribed by the WHO (World Health Organization 2011) and BIS (Bureau of Indian Standards 1993). The meteorological data (Fig. 1) were correlated with concentration of cations and salts.

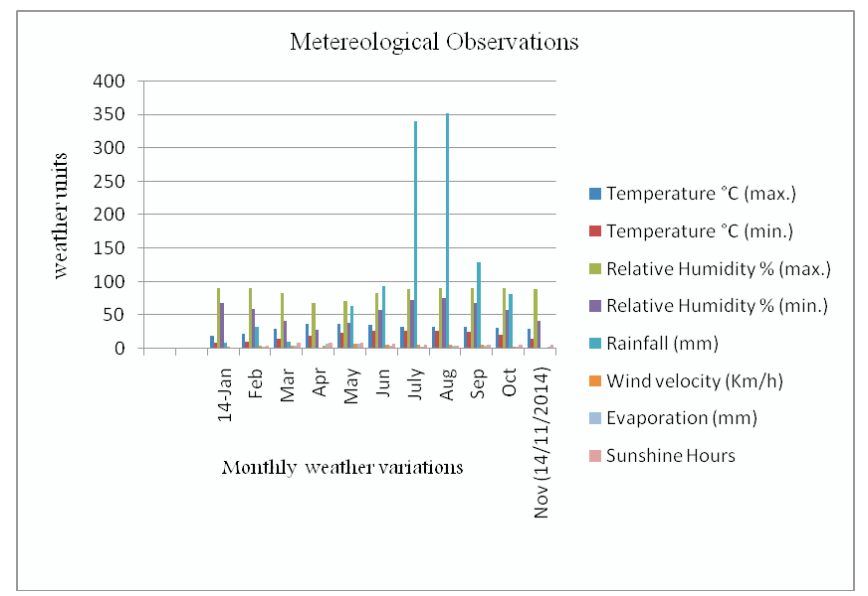

Fig.1 Meteorological data during the study period

\section{Results and Discussion}

The $\mathrm{pH}$ of water samples collected during premonsoon and post-monsoon period varied from 6.9 to 7.6 and 6.7 to 7.8 respectively (Table 1 and 2). Prescribed limits of $\mathrm{pH}$ by BIS is $6.5-8.5$ and by WHO is 8.5 . The $\mathrm{pH}$ was neutral during post monsoon season at all the sites except Sakara village which had slightly alkaline (Table 2). Roy et al. (2012) reported that $\mathrm{pH}$ of well water used for drinking in Nari area of Nagpur ranged from 7.3 to 8.3. The presence of carbonates, bicarbonates and some dissolved contaminant gases might be related to the alkalinity (Gaikwad et al. 2010).

Table 1. Water quality parameters of ground water collected during pre-monsoon period.

\begin{tabular}{llllll}
\hline Parameters & Dholi & Muraul & Lautan & Sakara & $\begin{array}{l}\text { Sakara } \\
\text { Bazitpur }\end{array}$ \\
& & & & & \\
\hline $\begin{array}{l}\text { No. of samples } \\
\text { pH }\end{array}$ & 4 & 4 & 4 & 4 & 4 \\
EC $\left(\mu \mathrm{Sm}^{-1}\right)$ & $7.1-7.4$ & $6.9-7.3$ & $7.1-7.6$ & $7.3-7.5$ & $7.0-7.3$ \\
TDS $\left(\mathrm{mL}^{-1}\right)$ & $754-823$ & $805-831$ & $534-664$ & $860-975$ & $732-760$ \\
Chloride $\left(\mathrm{mgL}^{-1}\right)$ & $520-640$ & $630-650$ & $425-470$ & $640-725$ & $540-560$ \\
Carbonate $\left(\mathrm{mLL}^{-1}\right)$ & $15.0-27.0$ & $9.8-12.0$ & $48.9-62.1$ & $26.0-36.8$ & $9.6-12.0$ \\
Bicarbonate $\left(\mathrm{mL}^{-1}\right)$ & NIL & NIL & NIL & NIL & NIL \\
Phosphate $\left(\mathrm{mg} \mathrm{L}^{-1}\right)$ & $510.0-534.0$ & $456.0-567.0$ & $268-304$ & $302-490$ & $326-400$ \\
Total alkalinity $\left(\mathrm{mgL}^{-1}\right)$ & $2.4-4.0$ & $4.6-6.8$ & $6.2-9.0$ & $6.4-8.6$ & $3.0-5.6$ \\
Total hardness & $101.5-120.8$ & $96.5-132.0$ & $108-139.6$ & $150-188.3$ & $139-176.0$ \\
$\left(\mathrm{mgL} L^{-1}\right)$ & $138.9-180.0$ & $120.5-140.6$ & $168.0-198.5$ & $186.5-210.0$ & $152.6-183.0$ \\
Sodium $\left(\mathrm{mgL}^{-1}\right)$ & $40.2-60.0$ & $19.7-30$ & $15.8-24.0$ & $44.0-73.0$ & $10.0-16.6$ \\
Potassium $\left(\mathrm{mgL}^{-1}\right)$ & $2.1-5.1$ & $3.6-7.0$ & $1.6-3.2$ & $6.0-8.0$ & $1.4-3.6$ \\
\hline
\end{tabular}


Table 2. Water quality parametersof ground water collected during post-monsoon period

\begin{tabular}{llllll}
\hline Parameters & Dholi & Muraul & Lautan & Sakara & $\begin{array}{l}\text { Sakara } \\
\text { Bazitpur }\end{array}$ \\
\hline No. of samples & 4 & 4 & 4 & 4 & 4 \\
pH & $6.9-7.2$ & $6.8-7.2$ & $7.0-7.4$ & $7.5-7.8$ & $6.7-6.9$ \\
EC $\left(\mu \mathrm{Sm}^{-1}\right)$ & $814-920$ & $780-820$ & $540-590$ & $740-783$ & $640-690$ \\
TDS $\left(\mathrm{mgL}^{-1}\right)$ & $680-748$ & $645-710$ & $390-500$ & $500-610$ & $520-620$ \\
Chloride $\left(\mathrm{mgL}^{-1}\right)$ & $14.0-24.0$ & $11.0-18.0$ & $33.0-58.0$ & $26.1-31.0$ & $5.3-10.8$ \\
Carbonate $\left(\mathrm{mgL}^{-1}\right)$ & $\mathrm{NIL}$ & $\mathrm{NIL}$ & $\mathrm{NIL}$ & $\mathrm{NIL}$ & NIL \\
Bicarbonate $\left(\mathrm{mgL}^{-1}\right)$ & $480.9-549$ & $450.0-521.0$ & $268-310$ & $365-396$ & $350-380$ \\
Phosphate $\left(\mathrm{mgL}^{-1}\right)$ & $2.0-3.6$ & $5.0-6.0$ & $4.0-5.0$ & $6.8-11.8$ & $3.0-4.6$ \\
Total alkalinity $\left(\mathrm{mgL}^{-1}\right)$ & $98.0-105.0$ & $80.4-112.0$ & $100-112.8$ & $188.6-207.8$ & $162.6-188$ \\
Total hardness $\left(\mathrm{mgL}^{-1}\right)$ & $200.4-220.8$ & $177-195.4$ & $189--227$ & $230.8-261$ & $168.5-206$ \\
Sodium $\left(\mathrm{mgL}^{-1}\right)$ & $80.5-90.1$ & $25.6-36.8$ & $15-22.0$ & $68.0-78.6$ & $40.0-58.0$ \\
Potassium $\left(\mathrm{mgL}^{-1}\right)$ & $3.4-5.0$ & $4.8-8.0$ & $2.0-4.2$ & $6.4-13.0$ & $2.4-3.8$ \\
\hline
\end{tabular}

The EC of water samples varied from 534-975 $\mu \mathrm{Sm}^{-1}$. The highest electrical conductivity (860-975 $\mu \mathrm{Sm}^{-1}$ ) was recorded in Sakara village during premonsoon period (Table 1). The mean electrical conductivity of all the drinking water samples were higher than the limit $\left(400 \mu \mathrm{Sm}^{-1}\right)$ prescribed by World Health Organization. Raju (2007) reported that 23 per cent of tested samples were beyond the WHO guidelines in Cuddapah district of Andhra Pradesh. High values of electrical conductivity in water might be due to high accumulation of calcium, magnesium and sodium salts in the surrounding soil.

Total dissolve solids (TDS) in sampled water collected during pre-monsoon period varied from 425 to $725 \mathrm{mgL}^{-1}$. The maximum value $\left(725 \mathrm{mgL}^{-1}\right)$ was recorded in Sakara village, whereas low concentration (425 $\mathrm{mgL}^{-1}$ ) was Lautan village. The continuous intake of water with high TDS may cause kidney stones and heart diseases (Garg et al. 2009). The highest TDS (680$748 \mathrm{mgL}^{-1}$ ) was recorded in Dholi village during post monsoon period. About 81 per cent of the ground water samples had TDS beyond the recommended admissible limits of $500 \mathrm{mgL}^{-1}$ as per BIS. The chloride concentration in water samples varied from 9.6 - 62.1
$\mathrm{mgL}^{-1}$ during pre-monsoon period. It was high in Lautan village (48.9 - $\left.62.1 \mathrm{mgL}^{-1}\right)$ and the lowest concentration (9.6 - $\left.12.0 \mathrm{mgL}^{-1}\right)$ was observed in Sakara Bazitpur village. Its concentration varied from 5.34 to $58.8 \mathrm{mgL}^{-1}$ at the end of monsoon (Table 2). The higher chloride level (33.0 - $\left.58.4 \mathrm{mgL}^{-1}\right)$ was observed in water collected from Lautan village, while it was in lower range $\left(5.3\right.$ - $\left.10.8 \mathrm{mgL}^{-1}\right)$ in Sakara Bazitpur village (Table 2). The reduced level of chloride during post monsoon might be due to its dilution. All water samples had permissible limits of chloride as per prescribed limit of WHO and BIS.

Bicarbonate concentration in drinking water (Table 1 and 2) ranged from 268 to $567.4 \mathrm{mgL}^{-1}$ during pre-monsoon. The higher quantity of bicarbonates $\left(567.4 \mathrm{mgL}^{-1}\right)$ was detected in Muraul village than the other points. The bicarbonates content in post-monsoon sampled water varied from $268-559 \mathrm{mgL}^{-1}$ and majority of samples had their concentration above the recommended levels. Roy et al. (2007) reported bicarbonates content in well water ranging from 208 $\mathrm{mgL}^{-1}$ (rainy season) to $342 \mathrm{mgL}^{-1}$ in winter season of Nagpur district of Maharashtra. Elevated bicarbonate concentration in ground water might be due to presence 
of carbonaceous minerals in soil system. The phosphate content in water samples ranged from 2.4 to $9.0 \mathrm{mgL}^{-1}$ during pre-monsoon period and it was higher in Lautan village (Table 1). In post-monsoon water samples, the phosphate content varied from 2.0 to $11.2 \mathrm{mgL}^{-1}$ while elevated concentration of phosphate $\left(11.8 \mathrm{mgL}^{-1}\right)$ was associated in Sakara village. The alkalinity varied from 96.5 to $188.3 \mathrm{mgL}^{-1}$ during pre-monsoon period. The post-monsoon sample of Sakara village had higher value of total alkalinity $\left(207.8 \mathrm{mgL}^{-1}\right)$, whereas, lower total alkalinity was reported in Lautan and Sakara Bazitpur villages (Table 2). The alkalinity is not much harmful to human health though its presence in the water imparts unpleasant taste. All the water samples compared with BIS limits and the total alkalinity was found to be under the permissible limits prescribed by BIS (200-600 $\left.\mathrm{mgL}^{-1}\right)$ and WHO $\left(500 \mathrm{mgL}^{-1}\right)$.

The total hardness is an important factor which reflects the quality of potable water. The hardness of water mainly depends on the amount of calcium and/or magnesium salts in water. Total hardness varies from $121-141 \mathrm{mgL}^{-1}$ and $187-210 \mathrm{mgL}^{-1}$ in the Muraul and Sakara village, respectively during pre-monsoon period. Total hardness in post-monsoon water samples ranged from 169 to $261 \mathrm{mgL}^{-1}$. The maximum hardness (261 $\mathrm{mgL}^{-1}$ ) of water was detected in the Sakara village and minimum value $\left(177 \mathrm{mgL}^{-1}\right)$ was found in Muraul (Table 2 ). These water samples were found to be below the recommended prescribed limits of BIS (300-600 $\mathrm{mgL}^{-1}$ ) and WHO (500 $\left.\mathrm{mg} \mathrm{L}^{-1}\right)$. Sodium concentration in drinking water samples ranged from 10 to $73 \mathrm{mgL}^{-1}$ during pre-monsoon period (Table 1) and its concentration was low $\left(15 \mathrm{mgL}^{-1}\right)$ during past monsoon period (Table 2). The water samples were found to be within the safe limits $\left(200 \mathrm{mgL}^{-1}\right)$ prescribed by WHO. Similarly, potassium concentration varied from 1.4 to $8.0 \mathrm{mgL}^{-1}$ in pre-monsoon period while in post-monsoon sampled water it varied from $2.0-13.0 \mathrm{mgL}^{-1}$. The data (Table 2) revealed higher content of potassium in Sakara and lower in Lautan village. The values of potassium content in all the water samples were well within the prescribed limits of $50 \mathrm{mgL}^{-1}$ as per WHO standards (2011).

\section{Conclusion}

The drinking water collected from handpumps from Sakara and Muraul blocks of Muzaffarpur district of Bihar during pre and post-monsoon period indicated that phosphate, total alkalinity and potassium were found to be below the recommended permissible limit of WHO and BIS. The electrical conductivity, bicarbonates and total dissolved solids were above the potable limit of drinking water.

\section{References}

Ashfaq, A. and Ahmad, F. (2014). Quality of assessment of ground water at Agra district, India. International Journal of Current Research \& Academic Review 2, 304-308.

American Public Health Association (1989). 'Standard methods for the examination of water and waste water', $17^{\text {th }}$ edition. (Washington, D.C.)

BIS (Bureau of Indian Standards) (1993). Indian standard drinking water-specification (First Revision ), Edition 2.1, IS 10500:1991.

Deshmukh, C. K. and Urkude, R. N. (2014). Physicochemical and microbial status of Malkhed lake at Chandur railway, district: Amravati. The Bioscan 9, 677-682.

Gaikwad, G.S., Wankhade, A.V. and Maldhure, A.V. (2010). Hydrochemical characteristics of ground water (well and tube well) in the slum area of Bhoogaon, Wardha district, Maharashtra. Journal of Chemical and Pharmaceutical Research 2, 499-503.

Garg, V. K., Suthar, S., Singh, S., Sheoran, A., Garima, M. and Sai, S. (2009). Drinking water quality in villages of southwestern Haryana, India: Assessing human health risks associated with hydrochemistry. Environmental Geology 58, 1329-1340.

Krishnan, R. R., Dharmaraj, K. and Kumari, B. D. R. (2007). A comparative study on the physicochemical and bacterial analysis of drinking, borewell and sewage water in the three different places of Sivakasi. Journal of Environmental Biology 28, 105-108. 
Mariappan, V., Prabakaran, P., Rajan, M. R. and Ravichandran, A. D. (2005). Systematic study of water quality index among the physicochemical characteristics of groundwater in and around Thanjavur Town. Indian Journal of Environmental Protection 25, 551-555.

Raju, N. J. (2007). Hydrogeochemical parameters for assessment of groundwater quality in the upper Gunjanaeru River basin Cuddapah district, Andhra Pradesh, South India. Environmental Geology 52, 1067-1074.

Roy R. P., Jagdish Prasad and Joshi, A. P. (2007). Effect of sewage vs well water irrigation on soil properties around Nagpur district of Maharashtra, India. Bangladesh Journal of Agriculturaland Environment 3, 89-92.
Roy, R. P., Jagdish Prasad and Gupta, R. (2012). Assesment of well-water quality for drinking purpose. A case study in Nari area, Nagpur district, Maharashtra, India. Journal of Environmental Science and Engineering 54, 420-423.

Saxena, M. M. (1987). Environmental analysis - water, soil and air. Second Edition. Agro Botanical Publishers, India. 86, 121-125.

WHO (World Health Organization) (2011). Guidelines for Drinking Water Quality. Forth Edition, Geneva. 